\title{
Eyes wide shut
}

Il/legality and solidarity in housing struggles in (post)socialist Sofia and Caracas Mariya Ivancheva and Stefan Krastev

Abstract: This article presents the results of a collaborative ethnographic inquiry in contemporary Sofia and Caracas. Combining historical research and ethnography, we compare the ways in which a former and a current left-wing regime treat urban squatting. In both cities, squatters tend to be poor families escaping homelessness. In Sofia, "squatters"—usually of Roma origin — inhabit unregulated spaces deemed illegal after 1989. In Caracas, homeless families have been officially encouraged to squat but not declared legal occupants. A historical comparison shows both socialist governments turn a blind eye to extralegal housing practices. Benign, informal housing arrangements function to display solidarity with marginalized groups as a form of popular legitimacy. Yet, without formalized state protection, such arrangements produced a "surplus" population, vulnerable vis-à-vis global processes of capitalist reorganization.

Keywords: il/legality, leftwing regimes, (post)socialism, solidarity, squatting

In late 2010, the BBC ran a story that describes the "breeze-block shacks" built up to the twentysecond floor in "perhaps the most curious skyscraper in Venezuela," Centro Financiero Confinanzas, also known as Torre de David (Grant 2010). Named after its developer in the 1990s, the financier J. David Brillembourg, it is now run by the former prisoner Alejandro Daza as an informal housing project for seven hundred families. The article only briefly sketches the community inside as paying their bills and supporting the President Hugo Chávez, to give the 
final word to Sulemar Bolivar, the head of urban planning for the opposition mayor of Caracas, Antonio Ledezma. Bolivar condemned the vertical barrio as "a symbol of anarchy, . . . lack of government and of public inefficiency," blaming the government for the housing shortage in the city. The BBC reporter did not reflect on the reason for the Caracas housing crisis that started before Chávez (García-Guadilla 2007; Karst et al. 1973) or connect its current peak to the extended rainfalls that left hundreds of thousands homeless in December $2010^{1}$ —homeless to whom the Bolivarian government provided shelter (refugio) inside public buildings, schools, and hotels. $^{2}$

The BBC article and similar reports could be dismissed as the usually biased reporting against Venezuela and other socialist experiments in media in capitalist democracies. In an era of emergent movements for housing rights, against mass displacement and homelessness, the story of Torre de David was taken out of context and used to present both the government and the poor as villains. However, biased reporting aside, the focus on housing provision exposed a weakness, not exclusive to Venezuela (see Morton 1979), of many socialist governments. Often built in the aftermath of mass-scale destruction and dispossession through colonial regimes, wars, and economic crises, such governments must tackle enormous shortages of infrastructure and services for most of the population. While benevolent policies and practices exceed anything previously available to the poor, they often use quick fix solutions and rely on preexisting informal temporary arrangements to deal with deficits (Ivancheva 2015). It is therefore important to explore socialist governments' justifications for implementing and perpetuating arrangements that often leave affected populations in rather precarious positions.

To address this question, this article presents the results of collaborative, comparative fieldwork carried out by both authors in 2011 in Sofia and Caracas. Combining historical and 
ethnographic narratives, we compare the role of the Left in power with regard to informal practices of solidarity around housing provision in two cases of urban squatting. In both cities, "squatters" are poor families who would otherwise be homeless. In Caracas, they have been encouraged by the government since 2006 to squat in downtown skyscrapers. However, their status as homeowners has not been established, and their housing situation has not been declared legal. In Sofia, after the fall of state socialism in 1989, the occupation of unregulated spaces by squatters — usually of Roma origin —is deemed "illegal." The two capitalist cities, despite different geopolitical locations and historical precedences, have faced challenges on two similar levels that merit comparison. Both Sofia and Caracas have struggled to regulate informal housing solutions while trying to modernize throughout the twentieth century (Dimitrova 2013; Karst et al. 1973).

Both cities were also central to mass socialist redistribution aimed at the poor (Ivancheva 2015; Martinez 2010). The differences between the state socialist governments in the twentieth century, of which Bulgaria is a representative, and the Latin American pink tide socialisms of the twenty-first century are, of course, significant. They are located differently within the global world system and cycles of capital accumulation. An agrarian society that exited Ottoman imperial rule to find itself in European postimperial domination, when it embraced state socialism in 1944, Bulgaria had neither the Venezuelan petrol nor the diverse ethnic composition of a former Spanish colony engaged in slave trade. Both had, however, a semi-peripheral role in the world system division of labor, and a poor mass of population swept into urban centers through large-scale modernization projects in which cities grew fast to absorb the incoming labor force (Ivancheva 2015; Karst et al. 1973). While socialist governments addressed this new surplus population with welfare policies in both cities, we show their efforts were similarly half- 
hearted.

Beyond the two specific contexts, this article is also informed by the global historical context in which the two cities are immersed. More than one billion people worldwide currently live in occupied buildings or terrains to which they can rarely claim ownership rights (Davis 2006; UN-Habitat 2003). Informal housing settlements are characterized by precarious housing tenure, unsuitable location, poorly planned layout, and the dwellers' vulnerability to political control and arbitrary power (Duhau 2014: 167). Until recently, academic literature distinguished between land seizures and self-built housing in the developing world (Conway and Brown 1980; Smart 2001), as well as the fight of urban subcultures against privatization of public spaces and speculative practices of real estate developers in the Global North (Holm and Kuhn 2011; Martinez 2007). Since the crisis of 2008, the gap between the two groups has narrowed. We are witnessing an increasing number of cases in capitalist democracies where occupiers are migrant workers (Berner 2000; Smart 2001), who are often of Roma origin in Europe (Legros 2010).

Yet, an important context remains excluded from debates on socioeconomic divisions in global cities (Sassen 2011) and advanced urban marginality (Wacquant 2007). What distinguishes our two case studies from most contexts discussed in the literature is the context of the Left in power, in the case of Bulgaria in the past or, in the case of Venezuela, the present. We ask why and how, despite their egalitarian promises, these regimes perpetuated precarious housing arrangements for the poor. Undertaking this comparison we follow Thomas Aguilera and Alan Smart's insistence that in comparative research on squatting "conceptual, methodological and contextual problems can be overcome by adopting a political economy approach emphasizing toleration and formalisation policies as a common point of departure" (2017: 29). 
To compare two divergent cases of the Left in power, we focus on the concept of solidarity. Using the case of informal housing, we suggest some larger conclusions regarding the difficult and multi-scalar relation between socialist politics and in/formal welfare provision, and between macro- and microscale forms of solidarity in both countries. We show that when it came to housing, under the justification of solidarity, the socialist regimes in Bulgaria and Venezuela turn a blind eye to informal housing arrangements. Neither persecuting nor legalizing extralegal housing solutions allowed them to prioritize the needs of specific social groups. But that was achieved at the price of leaving others vulnerable to the restructuring of the capitalist system, which these regimes played—if reluctantly—a part in. We show that, while extending certain welfare policies to the poor, "benevolent" socialist states relied on accumulation of reproductive surplus by marginalized groups they did not prioritize in their policies.

While scholars have shown how this relates to the reproductive and care labor of women (Gal and Kligman 2000) and peasants (Kligman and Verdery 2011), we show such a claim is also valid for communities catering to their own housing needs. We argue the post-socialist developments in Bulgaria, where formerly neglected groups became vulnerable to housing poverty, can teach important lessons to Venezuela and future leftist governments. If welfare policies are based not on a large-scale social protection but only on a community-level informal solidarity, then socialist regimes fail to prevent the further marginalization of vulnerable groups. Immersed in a global capitalist system, where they must cater to the demands of accelerated market competition and a growing middle class with higher demands for access to services and infrastructure, socialist regimes also perpetuate their own dependency on a "surplus" population in precarious labor and housing situation. 


\section{Solidarity revisited: Scaling up social struggles}

Since the 1970s, financial and productive capital has evolved in new global cities thanks in part to the low wages of increasingly impoverished groups (Sassen 2011), producing what has been called the "new urban enclosures" (Hodkinson 2012). With the rise in prices of urban land, poor inhabitants have been collectively displaced from areas of investment interest or discretely forced to seek individual solutions in cheaper, more distant areas beyond the "new urban frontier" (Smith 2004). This process has produced growing urban "surplus" populations, which, as Tania Li (2010) has argued, are contingently tied to a process of capital accumulation. In many cases, they have been rendered useless in terms of a function otherwise deemed central to capital—labor surplus—yet valuable in a different way. Living in precarious housing arrangements and legal situations, oftentimes coupled with ethnic and racial stigma, such populations could tangentially contribute to the accumulation of capital by the state. They could do this first by providing for their own needs, de facto sponsoring the state welfare and, second, by consuming production of capital enterprises (Quijano 1980). In this, socialist regimes, not unlike capitalist states in the developed and developing worlds, were relieved to see themselves free from responsibility to treat their members as full citizens (Chatterjee 2008), worthy of providing them with housing and further services. Linking poverty with ethnic definitions allows an increasing number of people in capitalist democracies to live in a state of exception (Agamben 2005): the suspended legality of their citizenship, housing, or labor rights that excludes them from public services, education, health care, and stable jobs. The territorial and social stigma (Wacquant 2007) imposed on the social groups in need allows state bureaucracies to be presented as weak, while they violently suspend laws and deprive marginalized groups from the rights not just over property but also over certain categories of life (Das and Poole 
2004: 9). Socialist regimes, we show, also dwell on such practices, producing state of exception for certain groups of citizens.

What distinguishes the two cases we compare, at a first glance, is the issue of ethnic and racial difference. Roma in modern Bulgarian history have been treated as the ultimate "Other" and subjected to social and political marginalization only partially addressed by socialist governments (Buechsenschuetz 2000). Venezuela, on the other hand, has taken pride in being a "racial democracy": a society of mestizaje where social stratification is sharp but ethnic divisions are irrelevant. Yet, a tiny European elite uses the ideological construction of mestizaje to cover the deeply ingrained cultural and institutional racism in Venezuela, and conceal a close correlation between race, class, and power, working at the disadvantage of a majority of poor, indigenous Venezuelans and Afro-Venezuelans (Salas 2005). Furthermore, ethnicity and race play a comparable role in the housing situations in Bulgaria and Venezuela. Both Roma and poor Venezuelans of color were subject to policies of administrative erasure: Roma were labeled "proletarians" and "workers" by socialist governments, while indigenous poor were treated as "peasants" (Grekova et al. 2008; Salas 2005). Indigenous and Afro-Venezuelans were dispossessed of their communally cultivated rural land and pushed into urban poverty (Uzcategui 1995). Similar, if spatially reverse, logic was applied to Bulgarian Roma: mahalas were cleared from central Sofia and their inhabitants pushed into the margins (Ivancheva 2015). Private property, denied to marginalized ethnic groups, has become the physical and legal battleground of the new urban enclosures (Hodkinson 2012): even alternative informal solutions of minimum subsistence are increasingly privatized or - if carried outside the commercial frameworkcriminalized. Pushed to the margins of the state (Das and Poole 2004), poor and ethnically marginalized groups have resorted to violent subversive acts and communal solidarity. 
Gáspár Miklós Tamás (2015) has argued the concept of solidarity relates predominantly to the history of resistance of the labor movement since the industrial revolution. For him, it disregarded a legal yet oppressive and exploitative labor contract, challenged exclusive property rights of factory owners, and fought for a classless society. Early and mid-twentieth-century organized workers' struggles in advanced capitalist societies achieved better working and welfare conditions: a concession from capital to labor that temporarily quelled discontent and supplied working force to galvanize capital accumulation (Panitch and Gindin 2012). Yet, this story has been reversed. In the neoliberal era, regimes have started cutting public expenditure and subsidies toward workers' reproduction. This reversal has likened the status of workers to that of the "surplus" populations of unemployed and underemployed workers, pressed to migrate to big cities in search for work (Sassen 2011). Not regarded by governments as subjects of full human and workers' rights, they have been selectively excluded from welfare programs (Chatterjee 2008), such as the construction of social housing, and left to take care for themselves in various informal ways (Chatterjee 2004). As Li (2010) points out, social protection has always been racialized and spatialized, and notions of community self-reliance have given rationale for political and institutional choices of not extending official safety nets to marginalized populations. Thus, even though they have not been able to accumulate capital beyond basic livelihood needs, "surplus" populations have subsidized capital accumulation by providing their own reproduction, including housing construction. It is important, then, to look at new venues where informal arrangements through solidarity function not just as the manifestation of precapitalist forms living but also as a direct subsidy to capital accumulation (Portes 1983).

While foundational texts of anthropology discuss the concept of solidarity with reference to the Durkheimian transition from mechanic to organic solidarity in modern society, 
anthropologists have more recently refocused the discussion on practical community-based solidarity (Cabot and Rakopoulos 2016). This has increasingly been the case in relation to the ongoing economic crisis since 2008 that affected countries within the European and North American core alike. The focus of the concept has, respectively, shifted from mass-scale social regulation to microscale instances of communal practices of mutuality and altruism toward insiders and outsiders. Crisis-struck Southern Europe has proved a potent ground for such exploration. The collision of economic recession and refugee crisis also engendered instances of spontaneous solidarity among marginalized social groups (Rozakou 2016). And while some of these practices drew on local institutions, anthropologists saw such instances as signs of hope for “an 'alternative horizon' aimed at combating alienation and atomisation” (Papataxiarchis 2016: 205).

While the individualizing character of neoliberalism has long been exposed and solidarity (rather than charity) has been seen as a way to address it (Cabot 2016; Theodossopoulos 2016), a question remains: How can solidarity be scaled up as a component of society-wide political strategies? Clearly, interpersonal and group solidarity has emerged vis-à-vis the failure of welfare policies in capitalist democracies, galvanizing debates on to what extent the city, rather than the state, could be a meaningful site of struggle (see, e.g., discussions on radical municipalism by Zechner and Hansen 2015). However, as the historical enclosure of communal lands has brutally shown, informal community-based reproductive, care, and subsistence labor performed by women and marginalized groups have traditionally served as a "cheap" subsidy to capitalist accumulation (Federici 2004; Wilson 2010). Cities profit economically and politically from "illegal" "slums" existing next to them: "Poor informal cities largely survive because their inhabitants are so adept at making these places function, in ways that usually link their fates to 
established networks of power and profit" (Fischer 2014: 2). The dependence of leftist regimes on informal arrangements entrenches a core principle of capitalist accumulation at the heart of socialism.

In this, it is important to distinguish with Klaus Peter Rippe two types of solidarity: a family-, neighborhood-, or community-based concept of mutuality and altruism, and a formal, impersonal, "project-based" version of solidarity that does not require preexisting social ties. While the former type of solidarity is underpinned by the contradictions of the social relations that engender it, Rippe claims, the latter generates - in acts of help toward stranger - new civic virtues, loyalties, and conceptions of social justice (1998: 257-259). Engaged in defending the liberal tradition from its communitarian critiques, Rippe uses the distinction to defend individual and market freedom from societal and state intervention. We show, instead, that while this analytical distinction is necessary, the lesson of past socialist regimes is different: sustainable social change requires an integration rather than further differentiation between these two types of solidarity. Large-scale policies of solidarity that address social suffering should take into account institutions developed by grassroots practices of solidarity yet not rely on them for subsidy. Scaling up their policies in the past anti-capitalist socialist regimes have leaned on such subsidy inherited from previous regimes. Instead of turning them into sites of intervention and struggle against capitalism, they have tailored welfare to an abstract aggregate. Not analyzing and addressing preexistent institutional and social arrangements, socialist governments have built the new socialist modernity with a blind eye of informality and vulnerability. By denying marginalized ethnic communities in housing poverty full social protection, they have fed off the reproductive surplus of their self-exploitative practices. We argue that learning from such failures of former socialist regimes and turning informality in a key site for struggle against 
capitalism is imperative for future projects aiming to achieve large-scale social transformation.

\section{Squatting in socialist Caracas: A quest for legality and solidarity}

Urban squatting (invasión, toma) is not new in Caracas, a city established in an act of colonial land seizure. Situated amid the steep valley of the Guaire River, the city grew rapidly in the twentieth century. While it exceeded 20,000 people in the interwar period, it was approaching four million by the end of the 1990s (Wiesenfeld 1998). Rapid urbanization made land a scarce resource. Self-constructed barrios (neighborhoods) were started by occupations of municipal or private land (Gómez 2007). The modernizing effort of "progressive dictator" Marcos Pérez Jiménez, who accommodated 180,000 residents into newly built "superblocks," was unique in twentieth-century Venezuela (Velasco 2015). Subsequent liberal governments limited construction and regulation, maneuvering between preelection benevolence (donating bricks and piecing together infrastructure) and post-electoral repression (Karst et al. 1973). With unemployment rising, and migrants from rural settings and refugees arriving from neighboring countries, barrio dwellings remained the only solution to a deepening housing crisis (GarcíaGuadilla 2007: 50-51). The global financial crisis of the 1980s and the Latin American debt crises made many big corporations close their offices. Legendary skyscrapers in downtown Caracas such as Torre Viasa, Torre Confinanzas, Torre Radio Continente, which served as symbols of the 1970s oil bonanza, were left derelict (Romero and Díaz 2011). After an agreement with the IMF in 1989, the government reduced direct investment in local infrastructure and housing and granted municipalities more decision-making power (Mitchell 1998: 6). The rich Caracas neighborhoods Chacao and El Hatillo split, respectively, from municipalities Sucre and Baruta, which they shared with poor barrios, to receive an equal 
municipal budget despite their lower population density (7). Property prices skyrocketed as the tiny rich municipalities invested in local medical, police, and transport services. While barrios mushroomed on hillsides in the vastly underfunded huge municipalities, squatters found refuge in the abandoned skyscrapers in downtown Caracas.

In 1999, Chávez's government inherited a dire housing crisis: while more than 90 percent of the population was living in the cities, more than 50 percent could not afford to rent accommodation or buy property (García-Guadilla 2007: 51). Moreover, in the first days of Chávez's government, torrential rain caused landslides that left hundreds of thousands homeless in poor areas particularly around Caracas (Fassin and Vasquez 2005). To tackle these problems, Chávez's government drew on a long history of grassroots urban organizing in the formation of Comités de Tierra Urbana (Committees of Urban Land-CTUs), slowly regulating barrio properties (García-Guadilla 2007; Martinez 2010). Chavista Mayor Juan Barreto initially started expropriating buildings for the benefit of the tenants who were not allowed to buy their longterm dwellings (Fox 2006), and threatened to expropriate lavish golf courses spreading amid barrios. ${ }^{3}$ The gradual land entitlement of the members of the seven thousand CTUs (Martinez 2010) showed a benevolent attempt of the socialist government to fight the housing crisis. But the annual flooding left thousands homeless and made building on hilly outskirts areas close to infrastructure and transport increasingly risky (Fassin and Vasquez 2005). In 2002, downtown derelict buildings were nationalized and placed under the jurisdiction of the State Fund of the Deposit and Bank Protection. The government's lack of official sanction of occupations in the new Law of Property of Urban Land (NABRV 2006) that promised legitimacy to all who sought regulation via CTUs was seen as a green light for urban squatting. Until 2009, about eight hundred buildings in the city were occupied. ${ }^{4}$ 
"We never thought we would be squatting in our lives," said Señora Mari, who led the occupation of what we call Torre TeleVenezuela in 2006. "In the 1990s, my husband and I were saving money to buy an apartment, but the investor disappeared with our money. We were left with nothing to pay rent." Sitting amid Mari's cozy, purple-painted living room in the derelict but fully populated building, she and her neighbor Señora Rosa recalled a televised speech of Chávez that triggered the wave of occupations. "We realized we had a right to free housing," said Mari. Rosa added: "People searched the internet for empty buildings. We found TeleVenezuela empty for 15 years." Mari went into minute detail of their occupation, her voice trembling with excitement: "Fourteen families gathered at Plaza El Venezolano. It was dark. We walked, the blood throbbing in our veins. At one point, we realized half the people had silently left the group." When they reached the building, the night guard ran away. The old lady laughed: "We slept inside. Unforgettable, we heard all kinds of noises. Then for two weeks we cleaned ... Those who left earlier only came when it was clean."

Having occupied the building, Mari and her neighbors waged a struggle to be considered a lawful collective of citizens in need of housing. They diligently documented everything in a well-organized checkered green notebook. Mari and Rosa showed us reports, architectural drawings, all kinds of measurements, minutes of meetings. The two women insisted there was no space for error: squatters had to be more accurate than state officials, preempting any legal request for evidence. Yet, even when they registered a legal entity — the Comite Provisional de Vivienda (Provisional Housing Committee)—neither the Minister of Housing and Habitat nor other authorities responded to their demands. "We were considered illegal," the two women said in unison. Their "illegality" became a bigger problem when a gang led by Yasmin, "The Mother" (La Madre), allegedly related to famous government supporter, Lina Ron, started evicting some 
of their neighbors and collecting rent from new inhabitants. "Crime and drug dealing started, but when we called the police, they refused to come: they said we are illegal!" Mari shrugged. "But all parties would canvass before election," Rosa added bitterly.

Beyond spontaneous occupations like Torre TeleVenezuela, a various groups claimed space in Caracas's vertical barrios. The Marxist-Anarchist Comité Nacional de Los sin Techo (National Homeless Committee) used detailed reading of historical laws to claim legality of all occupations. Their squats also had a food supply and recreational and educational programs. Evangelical churches also found space in emptied skyscrapers. As the BBC reportage reveals, the newborn Christian and former prison inmate Reverend Alejandro Daza has controlled the notorious Torre De David. According to the building's inhabitants of the giant 42-story block, Daza took in the poorest and neediest who knocked on his door. He organized the building, appointing coordinators for each floor and holding regular meetings to discuss arising issues and improvements. Like Torre TeleVenezuela, Daza and his neighbors sought to legitimize their status. He told us: "People have constructed good housing plots. We achieved higher security inside than out on the streets. We registered a cooperative. We invited the government programs [misiónes]. We want to show we are not scum: we are citizens, a decent community.”

We met the inhabitants of these and other vertical barrios in the summer of 2011, months after the great December 2010 floods. The recently announced Gran Misión Vivienda promised housing units for two million people, prioritizing those displaced by the current disaster and living in refugios (PSUV 2011). New houses started appearing in downtown Caracas, but most of them were still hours of travel from the city center, where most formal employment was concentrated. To meet needs of more central accommodation, the government created an official Movimiento de Pobladores (Settlers Movement-MP): a squatters' movement that "officialized" 
occupations. As many of our informants said, this group cooperated with gangs and often charged rent. Yet, only people who moved to refugios or MP squats were given new houses. While refugio dwellers were called "dignified citizens" (dignificados), Chávez denounced those in the autonomously squatted buildings in the center as "bourgeois traders and mafia members" (Villalobos 2010). This pushed people like Señoras Mari and Rosa's at Torre TeleVenezuela into refugios. Pointing to her suitcase, Rosa said she found it unfair that their housing situation did not make them eligible for new homes: "We are bottom of the list, below people from barrios as if we are less legal, despite our struggles." The refugio was last hope to get subsidized flats.

The experiences of the people in Torre TeleVenezuela and Torre de David show that occupations become the new frontier of struggle within new left-wing regimes, both in symbolic and in physical terms. The multiple inherent crises and contradictions from previous regimes put a heavy burden on left-wing movements in their fight for redistribution and profound social change. They are accompanied by a legal framework that suspends legality for those devoid of rights. And while gradual improvement of infrastructure and land tenure has been tried with mixed success in informal spaces in Venezuela and elsewhere in Latin America (see Duhau 2014), the squats remain in a state of exception: a space where vulnerable communities are left to take care of themselves. Beyond the maintenance and sanitation of derelict and often dangerous buildings, their self-care extended into the symbolic domain, in the necessity to fight territorial stigma (Wacquant 2007). Authorities do not recognize them as "decent" and "legal" citizens. Self-organizing that achieves only "exceptional, temporary, contextual victories” against neoliberal governments in nonsocialist contexts (Chatterjee 2008: 57) does not go much further under socialist regimes. Not using its legal and material resources to solve the housing problem of such communities, socialist governments feed off their practices of solidarity. And while 
Venezuelan squatters still stood the chance of gaining a flat, their vulnerability is more visible through the lens our study in post-socialist Sofia.

\section{Squatting in post-socialist Sofia: Beyond legality and solidarity}

Since the beginning of the twenty-first century, Roma settlements (mahalas) in Sofia have been construed by Bulgarian institutions as "illegal ghettos." Yet, their history is much more complex. Most contemporary mahalas were built at the beginning of twentieth century as mixed neighborhoods. After 1878, thousands of peasants migrated to the capital of newly liberated Bulgaria. They lived in substandard housing, unauthorized shacks, and factory barracks at the outskirts of Sofia with little access to infrastructure and services. Still, because of the housing shortages, these shantytowns were gradually legalized by the state (Dimitrova 2013; Gigova 2011). After 1944, when the Bulgarian Communist Party seized power, the next migrant wave, including Roma families, came from the countryside to Sofia to work in the heavy industries. In its attempt to resolve the housing crisis, the Communist Party initially treated Roma as potential proletarians. Their goal was to "erase the cultural difference of the Roma and transform them into socialist workers" (Grekova et al. 2008: 53). The way to do that was to desegregate "Gypsy neighborhoods, whose bad living conditions result in backwardness and conservatism of Gypsy consciousness." (77). According to a series of decisions of the Communist Party's Central Committee, Roma families were eligible for flats in new housing estates but had to be “desegregated” among ethnic Bulgarians (91). "Desegregation” efforts, however, were greatly hampered by a slowdown in construction of new buildings and the proliferation, despite high egalitarian ideas, of racist and classist institutions and practices in socialist Bulgaria.

State socialism's policies of treating Roma as "workers" had already changed in the late 
1940s (Ivancheva 2015). Following an attempt of some Muslim Roma to flee Bulgaria and claim Turkish citizenship upon the border closure under Kemal Atatürk in 1948, Bulgaria introduced specific racialized policies against Roma “Turkification” (Marushiakova and Popov 2012: 109110). This process escalated in the late 1970s, giving rise to the "Renaissance process" of the early 1980s: the forced renaming and assimilation of Roma communities, which had its precedents in earlier decades of state socialism (Ivancheva 2015). One such policy, beyond the closure of Roma community houses and media, was the separation of Roma pupils from their families and their segregation in short-term schools that disqualified them from university entry (Buechsenschuetz 2000). Another policy entailed the appointment of Roma mayors: low-level state employees, usually of Roma origin, who solved problems in the mahalas so that local discontent did not spill into the city. During big international public events, Roma neighborhoods were often bulldozed and their inhabitants placed in "temporary accommodation" outside big cities (Kolev 2003). Ethnic Bulgarians, sometimes displaced along with the Roma, were allowed to move out, and the neighborhoods remained segregated (Ivancheva 2015). The result—lowskill employment and deep segregation of Roma people — was aggravated with the Renaissance process: Roma, about 10 percent of the whole population, were obliterated from the public narrative, and walls were built around mahalas (Buechsenschuetz 2000; Grekova et al. 2008). While the socialist regime produced millions of units of public housing, unprecedented before and after state socialism, most were used by the nomenklatura, the military, and the police for housing and summer homes (Ivancheva 2015).

Granny Vassilka, a 70-year-old Roma woman, spent the past 50 years in one of the small pockets of shanty houses, clustered around the 1970s built socialist blocks in Serdika, a neighborhood in the Vazrazhdane ("Renaissance") municipality. Until the early 1970s, 
Vazrazhdane was a poor neighborhood where Jews, Roma, and migrants from the interior lived, many in shacks (Dimitrova 2013). During socialism, its inhabitants, like Vassilka and her husband, were factory workers in Sofia's growing industrial belt. Nowadays, the couple live on their minimum pensions, which also provide for their unemployed four children and 36 grandchildren, most of whom live in rooms built around the original shack. In the beginning of the century, the family of Vassilka's husband and seven other families settled here. In the 1970s, most of the shacks were demolished and replaced with several panel blocks. Pockets of Roma shacks survive, encircled by such blocks. Like Vassilka's family, other neighbors were offered flats in the new blocks: two-room flats for dozens of family members. "My daughter took the small flat," Vassilka shrugged. "We were asked to register for other flats. Forty years waiting, no result.” So, while some Roma families received apartments like Vassilka's family, most kept their unregulated shack to host their large households. While the Communist Party issued orders to Sofia's People's Councils to destroy illegal Roma dwellings, the severe housing shortage made demolition impossible. Most unregulated Roma settlements were silently tolerated if never legalized. Vassilka remembered, "They threatened us often but no one ever came."

Serious challenges to unregulated Roma dwellings came only with the end of state socialism and the Bulgarian transition to market economy. While Roma integration was allegedly an EU and government priority, "illegal Roma ghettos" were invented to justify dispossession. By the early 2000s, these changes were mostly discursive. Illegal housing entered policy documents as one of the key factors impeding full integration of Roma in Bulgarian society (UNDP 2012). Between 25 and 70 percent of the housing occupied by the Roma minority was estimated to be illegal (OSI 2002: 23). While Roma integration rhetoric was a focus of successive neoliberal governments, shifts in state property consolidated the narrative of "illegal 
Roma ghettos." After 1999, in a campaign toward "rationalization of resources," the status of "state-owned land" was changed to "public-private land," that is, land that municipalities could sell to private investors (BMRDPW 1999). The Sofia municipality started working toward "a solution to the overall problem with illegal buildings" (BHC 2010). Drastic measures against "illegal Roma ghettos" in Sofia ensued. In 2001, the shacks of 30 Roma from the Asanova mahala in the neighborhood of Lyulin were removed. Their inhabitants were relocated to caravans near Sofia's ring road. Two hypermarkets were built over the "illegal Roma" settlement (Garcheva 2004). In August 2005, another 22 unregulated Roma houses were demolished in Hristo Botev. In 2008, a special working group, created by the municipality to find a long-term solution for the "illegal ghettos" in Sofia, inquired about the possibility of accommodating displaced Roma from Sofia in empty military barracks.

Meanwhile, because of its central location, Vazrazhdane municipality's real estate prices skyrocketed. Land around the first shopping mall in the capital suddenly became highly popular. In 2003, the Sofia City Council adopted a plan of a "consistent construction policy for economic redevelopment." Inhabitants of Batalova Vodenitsa, where Vassilka lives, and similar mahalas were called by officials "invaders," "contaminating" previously "civilised areas" and turning them into "wild ghettos" of "illegal buildings" (BHC 2010). In the beginning of 2005, a private investor bought municipal land in immediate proximity to the Roma shanty houses in Batalova Vodenitsa from the Sofia City Council. Soon after, all 180 inhabitants of Batalova Vodenitsa received one-week eviction notices. Together with 20 other families, Vassilka's family was mobilized by Reverend Yonchev. Supported by the Bulgarian Helsinki Committee (BHC), they brought the eviction case to court. Bulgarian legal institutions found the municipality's eviction order lawful. The Batalova Vodenitsa case was brought up before the European Court of Human 
Rights (ECHR) in Strasbourg. The BHC used the Roma origin of the residents to signal the biased, racist decision of the Bulgarian institutions. The ECHR urged the Sofia municipality to provide housing to the Roma before demolishing their garrets. The Sofia municipality, home to two million people, had no public housing stock left to allocate flats to the twenty families. They stayed in their current shacks with little hope for secure housing, their court victory called hatefully "Roma privilege" by the majority population.

What led to Batalova Vodenitsa? The Bulgarian state socialist authorities silently tolerated occupations of state-owned lands and buildings, as de facto access to housing for socially excluded populations. Yet, leaving settlements unregulated and not legalized meant granting their inhabitants informal use rights but not clearly defined rights to property. This also meant public budgets could prioritize housing for certain groups while leaving others to take care for their own housing (Ivancheva 2015). Against this background, the regime change of 1989, the result of a larger and impending crisis, came as a shock to Roma communities. Under the renewed emphasis on private property, informal practices tolerated by the socialist regimes had no legal standing. Roma settlements became vulnerable to displacement and housing poverty. As in contemporary Venezuela, the Left in power in socialist Bulgaria tolerated informal arrangements to gain legitimacy and extend solidarity. By not granting residents sustainable housing rights and welfare protection, state institutions produced areas of exception, isolation, and marginality on which self-sustaining practices it could dwell. This frail solidarity was subverted by the new urban enclosures post- 1989 that rendered illegal those that the socialist regime had left informal (Ivancheva 2015).

\section{Conclusion}


In this article, we compared some of the dilemmas faced by two left-wing regimes in power, dis/engaging with marginalized urban populations and their informal housing arrangements. Within heightened expectations for redistribution and state engagement with social provision, both regimes have designed large-scale programs for social housing. Yet, informal solutions deemed "occupation" and "squatting" remained the only option for significant parts of disenfranchised populations in Sofia and Caracas. Despite their attempt at large-scale redistribution inclusive to "surplus" populations, in their housing policies, both socialist regimes have de facto distinguished between "deserving" and "undeserving" citizens and left certain groups in precarious legal conditions. Increasingly integrated in the global capitalist system and its accumulation pressures, these governments have abandoned full social protection of marginal groups and extracted reproductive surplus from their self-sustaining practices.

Like under the selective hegemony of neoliberal governance (Smith 2011), socialist government's inconsequential, partial, and selective legalization and regulation of occupations have left the poorest in a state of exception and exposed them to great vulnerability. Ethnically and socially stigmatized populations under socialism are forced to mobilize and self-organize their informal housing structures in order to defend their right to housing, reverting to communal forms of solidarity. We argue that, along with the reproductive and care labor of women and peasants, self-organized informal housing solutions of marginal populations also provide an unofficial and often unaccounted for subsidy to official capital accumulation used for the modernizing expansion of socialist states.

A stream of research of informality dating from the 1970s and reemergent since the 2008 crisis, celebrates the agency and resilience of poor, self-organizing communities in advanced capitalist regimes. Such arguments have received a new spin with postcrisis self-organizing 
practices in countries as Greece and Spain, celebrated for their left turn. Yet, the easiness with which such arrangements, reminiscent of the UK Conservative government's idea of the Big Society, are used by socialist governments leaves us alert. The finding that such communities remained vulnerable and in need of self-protection under large-scale projects for social transformation is an alarming revelation. Building the new socialist modernity based on community practices of subsistence, leftist governments denied communities the full social protection that would shield them from the exploitative and self-exploitative practices that such informal arrangements often engender.

The two cases we focused on pose a question: How do we integrate communal solidarity into society-wide political strategies without normalizing vulnerability? The experience of socialist regimes in Bulgaria and Venezuela suggest large-scale policies that address social suffering should take into account but not exploit relations and institutions developed in grassroots practices of solidarity. $\mathrm{Li}$ (2010) sketches a possible way out of this conundrum in her description of the dynamic alliances and assemblages of social agents that operate at different social scales to make policies of "make live" possible. These alliances stretch from the informal institutions of marginal communities to benevolent agents within state and make sure their inherent logics of discriminating between deserving and undeserving parts of the population are held in check. These alliances are always articulated and rearticulated in the course of political struggles and thus integrating large-scale social protection and communal solidarity remains one of the key terrains of radical leftist politics in the twenty-first century.

Mariya Ivancheva is Lecturer in Higher Education Studies at the University of Liverpool. Her doctoral dissertation explored, ethnographically, the development of the Bolivarian University of 
Venezuela. Since then, she has worked as a postdoctoral research fellow on various projects, including exploring housing in (post)socialist Sofia and Caracas, the casualization of labor in postcrisis academia, and the impact of digital technologies and marketization processes on inequalities in universities in South Africa and the United Kingdom. She has published widely on the present and the legacy of socialist regimes, and the role of universities in processes of social change. Email: m.ivancheva@ leeds.ac.ukliverpool.ac.uk

Stefan Krastev is a Doctoral Candidate in Sociology at the Sofia University who holds a BA in Ethnology and an MA of Sociology and Social Anthropology. He is interested in the Roma, ethnic minorities, urban marginality, racism, and visual media. His doctoral research is focused on aspects of the process of financialization of social reproduction among Roma and other precarious populations in Bulgaria: the proliferation of management techniques such as "calculation of risk" and "personal ratings," related to the development of "fast credits" industry, and people's attempts at subverting them. Email: stefankrastev@gmail.com

\section{References}

Agamben, Giorgio. 2005. State of exception. Chicago: Chicago University Press.

Aguilera, Thomas, and Alan Smart. 2017. "Squatting, north, south and turnabout: A dialogue comparing illegal housing research.” In Public goods versus economic interests: Global perspectives on the history of squatting, ed. Freia Anders and Alexander Sedlmaier, 2955. London: Routledge.

Berner, Erhart. 2000. "Learning from informal markets: Innovative approaches to land and Housing Provision.” Paper presented at the ESF/N-AERUS and UNRISD Workshop 
"Cities of the South: Sustainable for whom?" Geneva, 3-6 May.

https://www.ucl.ac.uk/dpu-

projects/drivers_urb_change/urb_economy/pdf_infor_econo/ESF_NAERUS_Berner_info rmal.pdf.

BHC (Bulgarian Helsinki Committee). 2010. "Government Position on Batalova Vodenitsa on the admissibility and the content of appeal no. 25446 / 06 before the European Court of Human Rights-Yordanova and others against Republic of Bulgaria."

BMRDPW (Bulgarian Ministry of Regional Development and Public Works). 1999. "Law of public property.” Accessed 3 September 2018. http://www.mrrb.government.bg/docs/bb64a67a8f35f3727985dd11fdae93d6.doc

Buechsenschuetz, Ulrich. 2000. Minority policy in Bulgaria: The politics of the Bulgarian communist party toward Jews, Roma, Pomaks, Turks (1944-1989). Sofia: International Center for Minority Studies and Intercultural Relations.

Cabot, Heath. 2016. “'Contagious”” solidarity: Reconfiguring care and citizenship in Greece's social clinics.” Social Anthropology 24 (2): 152-166.

Cabot, Heath, and Theodoros Rakopoulos. 2016. "Solidarity: The egalitarian tensions of a bridge-concept." Social Anthropology 24 (2): 142-151.

Chatterjee, Partha. 2004. The politics of the governed: Reflections on popular politics in most of the world. New York: Columbia University Press

Chatterjee, Partha 2008. "Democracy and economic transformation in India." Economic and Political Weekly, 19 April, 53-62.

Conway, Dennis, and Juanita Brown. 1980. "Intra-urban relocation and structure: Low-income migrants in Latin America and the Caribbean." Latin American Research Review 15 (3): 
$95-127$.

Das, Veena, and Deborah Poole, eds. 2004. Anthropology in the margins of the state. Santa Fe, NM: School of American Research Press.

Davis, Mike. 2006. Planet of slums: Urban involution and the informal working class. London: Verso.

Dimitrova, Veronika. 2013. "Becoming homeless with a home? State and municipal policies and struggles for 'resolving' the homelessness problem in the interwar period." Critique and Humanism 42 (1): 367-381.

Duhau, Emilio. 2014. "The informal city: An enduring slum or a progressive habitat.” In Fischer et al. 2014: 150-169.

Fassin, Didier, and Paula Vasquez. 2005. "Humanitarian exception as the rule: The political theology of the 1999 Tragedia in Venezuela." American Ethnologist 32 (3): 389-405.

Federici, Silvia. 2004. Caliban and the witch. New York: Autonomedia.

Fischer, Brodwyn. 2014. "Introduction.” In Fischer et al. 2014: 1-7.

Fischer, Brodwyn, Bryan McCann, and Javier Auyero, eds. 2014. Cities from scratch: Poverty and informality in urban Latin America. Durham, NC: Duke University Press.

Fox, Michael. 2006. "Mayors of Venezuela's capital engage in verbal fistfight." Venezuelanalysis, 30 August. https://venezuelanalysis.com/news/1915.

Gal, Susan, and Gail Kligman. 2000. Reproducing gender: Politics, publics, and everyday life after socialism. Princeton, NJ: Princeton University Press.

García-Guadilla, Maria-Pilar. 2007. “Ciudadania, inclusión y autonomia en las organizaciones sociales bolivarianas: Los comites de tierra urbana" [Citizenship, inclusion, and autonomy in Bolivarian social organizations: Urban land committees]. Cadenas de 
CENDES 24 (66): 47-73.

Garcheva, Veselina. 2004. "Roma with illegal houses will be evacuated to military barracks." [In Bulgarian.] Sega, 31 May. http://www.segabg.com/article.php?id=133335.

Gigova, Irina 2011. "The city and the nation: Sofia's trajectory from glory to rubble in WWII." Journal of Urban History 37 (2): 155-175.

Gómez, Suzuky M. 2007. "De la Hacienda La Dolorita a la metrópolis caraqueña: Historia de una exclusión" [From Hacienda La Dolorita to the Caracas metropolis: History of exclusion]. CONHISREMI 3 (1): 1-25.

Grant, Will. 2010. "Venezuelan squatters bank on the future in office tower." BBC, 19 December. https://www.bbc.co.uk/news/world-latin-america-11942501.

Grekova, Maya, David Kyuranov, Veronika Dimitrova, Nevena Germanova, and Yana Markova 2008. The Roma in Sofia: From isolation to integration. Sofia: Iztok-Zapad

Hodkinson, Stuart. 2012. "The new urban enclosures." City 16 (5): 500-518.

Holm, Andrej, and Armin Kuhn. 2011. "Squatting and urban renewal: The interaction of squatter movements and strategies of urban restructuring in Berlin." International Journal of Urban and Regional Research 35 (3): 644-658.

Ivancheva, Mariya. 2015. "From informal to illegal: Roma housing in (post)-socialist Sofia." Intersections 1 (4): 38-54.

Karst, Kenneth, Murray L. Schwartz, and Audrey J. Schwartz. 1973. The evolution of law in the barrios of Caracas. Los Angeles: Latin American Center.

Kligman, Gail, and Kanthryn Verdery. 2011. Peasants under siege: The collectivisation of Romanian agriculture, 1949-1962. Princeton, NJ: Princeton University Press.

Kolev, Gospodin. 2003. A Gypsy in the central committee of the Bulgarian Communist Party. 


\section{Sofia: VINI.}

Legros, Olivier. 2010. “Les 'villages d'insertion': Un tournant dans les politiques en direction des migrants roms en région parisienne?" [The "insertion villages": A turning point in policies toward Roma migrants in the Parios region?] Revue Asylon(s) 8. http://www.reseau-terra.eu/article947.html.

Li, Tania. 2010. "To make live or let die? Rural dispossession and the protection of surplus populations." Antipode 41 (1): 66-93.

Martinez, Miguel. 2007. “The squatters' movement: Urban counter-culture and alterglobalisation dynamics." South European Society and Politics 12 (3): 379-398.

Martinez, Jennifer. 2010. "Negotiating Transformation in a Leftist State: An urban social movement and constructing a new agent of social transformation." Paper presented at the 29th International Congress of the Latin American Studies Association, Toronto, 6-9 October.

Marushiakova, Elena, and Vesselin Popov. 2012. Gypsies in eastern Europe. Sofia: Paradigma. Mitchell, Jeffrey. 1998. "Political decentralisation: A new tool for the segregation of urban space? The case of Chacao in Caracas, Venezuela." Paper presented at the 21st International Congress of the Latin American Studies Association, Chicago, 24-26 September.

http://www.monitor.bg/article?id=53474Morton, Henry W. 1979. "Housing problems and policies of Eastern Europe and the Soviet Union." Studies in Comparative Communism 12 (4): $300-321$.

NABRV (National Assembly of the Bolivarian Republic of Venezuela). 2006. "Ley especial de regularización integral de la tenencia de la tierra de los asentamientos urbanos populares" 
[Special law for the internal regularization of the tenure of the land of popular urban settlements]. Gaceta Oficial 38.480, 17 July.

OSI (Open Society Institute). 2002. Protecting minorities in Bulgaria. Sofia: OSI.

Panitch, Leo, and Sam Gindin. 2012. The making of global capitalism: The political economy of American empire. London: Verso.

Papataxiarchis, Evthymios. 2016. "Unwrapping solidarity? Society reborn in austerity.” Social Anthropology 24 (2): 205-210.

Portes, Alejandro. 1983. "The informal sector: Definition, controversy, and relation to national development." Review (Fernand Braudel Center) 7 (1): 151-174.

PSUV (Partido Socialista Unido de Venezuela). 2011. “Nace Gran Misión Vivienda Venezuela para resolver déficit habitacional" [Gran Misión Vivienda Venezuela is born to solve housing deficit]. Colarebo, 13 February.

Quijano, Anibal O. 1980. "The marginal pole of the economy and the marginalized labour force." In The articulation of modes of production, ed. Harold Wolpe, 255-288. London: Routledge.

Rippe, Klaus Peter. 1998. “Diminishing solidarity.” Ethical Theory and Moral Practice 1 (3): $355-374$.

Romero, Simon, and María E. Díaz. 2011. “A 45-story walkup beckons the desperate.” New York Times, 28 February.

Rozakou, Katerina. 2016. "Socialities of solidarity: Revisiting the gift taboo in times of crises." Social Anthropology 24 (2): 185-199.

Salas, Jesus Maria Herrera. 2005. "Ethnicity and revolution: The political economy of racism in Venezuela." Latin American Perspectives 32 (2): 72-91. 
Sassen, Saskia. 2011. The global city: New York, London, Tokyo. Princeton, NJ: Princeton University Press.

Smart, Alan. 2001. "Unruly places: Urban governance and the persistence of illegality in Hong Kong's urban squatter areas.” American Anthropologist 103 (1): 30-44.

Smith, Gavin A. 2011. "Selective hegemony and beyond-populations with "no productive function': A framework for enquiry." Identities 18 (1): 2-38.

Smith, Neil. 2004. The new urban frontier: Gentrification and the revanchist city. London: Routledge

Tamás, Gáspar Miklós. 2015. “On solidarity.” OpenDemocracy, 26 March. www.opendemocracy.net/g-m-tamás/on-solidarity.

Theodossopoulos, Dimitrios. 2016. "Philanthropy or solidarity? Ethical dilemmas about humanitarianism in crisis-afflicted Greece.” Social Anthropology 24 (2): 167-184.

UN-Habitat (United Nations Human Settlements Programme). 2003. The Challenge of Slums: Global Report on Human Settlements. London: UN-Habitat. https://www.un.org/ruleoflaw/files/Challenge\%20of\%20Slums.pdf.

UNDP (United Nations Development Programme). 2012. "The situation of Roma in 11 EU member states: Survey results at a glance.” https://fra.europa.eu/en/publication/2012/situation-roma-11-eu-member-states-surveyresults-glance.

Uzcategui, Cesar. 1995. “Aproximación al estudio de la política indigenista venezolana del siglo XIX" [Approximation to the study of Venezuelan Indianist policy of the nineteenth century]. Revista Montalban 28 (1): 195-207.

Velasco, Alejandro. 2015. Barrio rising: Urban popular politics and the making of modern 
Venezuela. Berkeley: University of California Press.

Villalobos, Marissel. 2010. "Chávez condenó la invasión u ocupación ilegal de Viviendas” [Chávez condemned the invasion or illegal housing occupancy]. Venelogia, 26 May. http://www.venelogia.com/archivos/3983 (accessed 22 September 2018).

Wacquant, Loic. 2007. “Territorial stigmatisation in the age of advances marginality." Thesis Eleven 91 (1): 66-77.

Wiesenfeld, Esther. 1998. "Entre la invasión y la consolidación de barrios: Analisis psicosocial de la residencia al desalojo" [Between the invasion and the consolidation of neighborhoods: Psychosocial analysis of the residence to the eviction]. Estudios de Psycologia 3 (1): 33-51.

Wilson, Tamar D. 2010. "Primitive accumulation and the labor subsidies to capitalism." Review of Radical Political Economics 44 (2): 201-212.

Zechner, Manuela, and Bue Rübner Hansen. 2015. "Building power in a crisis of social reproduction.” ROAR Magazine, 9 December. https://roarmag.org/magazine/buildingpower-crisis-social-reproduction.

\section{Notes}

1. "Venezuela floods and mudslides leave at least 25 dead," BBC, 2 December 2010, https://www.bbc.co.uk/news/world-latin-america-11897912.

2. "Habilitan más refugios en Caracas" [More shelters enabled in Caracas], Ciudad Caracas, 19 May 2011, 3.

3. "Venezuela to seize golf courses," BBC, 30 August 2006, http://news.bbc.co.uk/2/hi/americas/5297246.stm. 
4. "22 mil invasiones se han registrado en todo el país" [22 thousand invsaions have been registered throughout the country], Aporrea, 1 June 2009, http://www.aporrea.org/actualidad/n135523.html. 